\title{
Features of the Implementation of the "Academic Writing" Discipline at the Language Faculty in a Digital Educational Environment
}

\author{
Salimzanova D.A. \\ Naberezhnye Chelny Institute of Kazan (Volga region) Federal University, Naberezhnye Chelny 423800 \\ Email: gilfanova_di@list.ru
}

\begin{abstract}
In today's environment, an increasing number of educational organizations prefer to use various digital teaching methods. Teachers create and use various distance learning programs, including virtual classrooms, electronic educational resources, online platforms with the possibility of webinars in which students have the opportunity to give feedback in real time. One cannot fail to note the high level of productivity and convenience of this teaching method, since such tools of modern technologies make it possible to use a wide range of electronic resources to obtain high-quality knowledge. The article discusses the possibilities of using electronic educational platforms, as well as the structure of the electronic educational resource in teaching a foreign language at a language university in the framework of the discipline "Academic writing". The aim of the study is to consider the tools of the digital educational environment for the introduction of digital, visual, audio and video material, ensuring the effectiveness of students studying the basics of the discipline "Academic Writing" and the formation of academic competence and digital literacy skills. The study considers electronic educational tools and resources, the use and implementation of which the author of the article considers the most productive in the process of distance learning.
\end{abstract}

Keywords: Academic Writing, e-learning, digital educational environment, academic competence, education

\section{INTRODUCTION}

The academic writing discipline is based on theoretical knowledge of writing essays, scientific articles, abstracts, term papers, graduation thesises, dissertations and ways to increase academic literacy. The main goal of the discipline is to provide students with a holistic view of the theoretical and practical foundations of academic writing to form the professional competence of students on the basis of mastering the practical skills of using a professional conceptual and terminological apparatus for the discipline, using the strategy of creating digital literacy and the possibilities of using electronic resources and Internet technologies to solve practical and professional tasks in working with academic material in a digital educational environment. The traditional development of the discipline "Academic Writing" is carried out through the use of lecture material, practical exercises using teacher editions and various innovative educational technologies using active and interactive forms of conducting classes. As a rule, the following forms of work are used: project tasks in small groups.

implementing of business educational games, presentations and discussion of problems. Individual study of a student involves the study of scientific literature, conducting of group research, preparing reports and library-research papers, studying arrays of factual data, creating of presentations. Tasks performance requires the use of not only textbooks and manuals, but also the information contained in periodicals, in electronic thematic online dictionaries and full-text electronic libraries for the search for scientific materials. The existing electronic educational tools and resources allow the use and implementation of various forms of work with students to form professional skills and a high level of competence in the process of obtaining higher education [1]. The successful use of the electronic environment in the context of modernization of education in accordance with the work programs of the third-generation FSES disciplines creates the conditions for self-organized and self-regulatory training.

\section{METHODOLOGY OF RESEARCH}

E-learning systems are becoming an effective tool, designed to improve the quality of education through the competent planning of the academic workload, the management of teaching materials and the control of knowledge quality. The management of educational materials is carried out only with the availability of educational and methodological support, or, in other 
words, electronic educational resources (EER), which include electronic copies of print media, electronic interactive textbooks, multimedia presentations of educational material, computer testing systems, review lectures on audio and video media, computer simulators, virtual laboratories, intelligent training systems, training packages for applied programs, as well as information and communications unique technologies. The use of these technologies implies the existence of basic skills of students in the search and selection of information, cognition of the general rules for the formation of keywords for educational and research purposes on the Internet, as the analysis of educational material involves the use of the following search engines: Yahoo! thematically organized system; Google - a search engine for academic purposes; GoogleScholar - a database of research papers; AltaVista - an extensive database; Yandex - a popular Russian search engine; Rambler - a system for general search. In addition, you need skills in using standard programs from the Windows, Microsoft Office, Open office.org, PowerPoint, MovieMaker, Impress, and other packages. In the process of studying the discipline, it is necessary to use interactive training programs and multimedia technologists (slide presentations, interactive whiteboard, audio and video files) that allow a teacher to be creative in preparing the lesson, thereby increasing the motivation of students.

We would like to dwell in details on some of the tools for working in the digital educational environment - an electronic educational resource at the distance learning site of the Kazan (Volga) Federal University [2]. According to the requirements for the content of the resource, in the description of the resource, the author indicates the direction of preparation and the curriculum, according to which the work program of the discipline is implemented, the main content, which includes a brief summary of the discipline, content list, key-words, information about the authors and their contact details. In the main part of the course, the required content elements are: the table of contents of the course, the work program, a short abstract course with methodological instructions for teachers and students, a glossary of the discipline, a list of basic and methodological literature, a list of questions for selfcontrol, test or examination topics. At the discretion of the author, a list of open Internet resources, presentations on topics provided by the discipline, electronic versions of textbooks, lectures, teaching editions, and a welcoming video to the course can also be included in the main course of the program

The number of modules (topics) should correspond to those indicated in the work program of the discipline and its main sections: guidelines for students and teachers; glossary; literature; control unit; open electronic resources; training material to which worksheets with variable lexical and grammar exercises on the topic are attached, audio and video materials (training videos in the original language), tables and presentations (PowerPoint) for an accessible explanation of the topic material and its correction.

The electronic educational resource in the discipline "Academic writing" is now under development by the author. The theoretical material of the discipline is implemented through the following content of the discipline:

1. Academic writing style (What Is Academic Writing And Why Do We Need It? The term "academic writing". Academic writing skills. Main features of academic writing. Sentence Structure. Sentence Types. What is punctuation? Using Linking Words. Linking words showing contrast. Linking Words that Move the Discussion Along. General list of linking words and their meanings. Writing activities.)

2. Sentence structure (Four types of sentence: Simple sentence. Compound sentence. Complex sentence. Compound-Complex sentence)

3. Linking words and Punctuation (What is punctuation? Using of Commas in Academic writing. Using of Colons in Academic writing. Using of Semi-colons in Academic writing. Using of Run-on sentences in Academic writing.) 4. Plagiarism, summarising and paraphrasing (What is plagiarism? Summary and citation. Quotation and citation. Degrees of plagiarism. Acknowledging sources. Avoiding plagiarism by summarising and paraphrasing. Avoiding plagiarism by developing good study habits. The elements of effective paraphrasing. Techniques for paraphrasing. What makes a good summary? Stages of summarising).

5. Writing an abstract (What is an abstract? Why to write an abstract? When is it necessary to write abstracts? Qualities of a good abstract. How to write an abstract? What to include in an abstract? Format of an abstract. Types of abstracts. Descriptive abstracts. Informative abstracts. How is an abstract different to an introduction? Writing activities.)

6. Writing models (Writing of CV. The contents of a CV. Formal letters and emails. Letters and Emails. Reports, case studies and literature reviews. Writing reports. Essays and reports. Case studies and example case study. Literature reviews. Example literature review.)

7. Writing an essay (Writing longer essays. The process of researching and writing a longer essay $(2,000-5,000$ words). Example essay.)

8. Writing a research paper (What is a research paper? Parts of a research paper. The Introduction The general presentation. Purpose and the exact direction of the paper. A statement of intent from the writer. The Method. The Results. The Discussion. The Conclusion. The Reference List. The structure of a research report. IMRAD (Introduction, Methods, Results, [and] Discussion). The Title Page. Abstract. Introduction. Methods. Results. Discussion. conclusions. Acknowledgements. References. Two major types of research papers: argumentative research paper, analytical research paper.

\section{RESULTS}

The course program was developed for senior students of "Linguistics" training program [3]. The textbook of Stephen Bailey [4] was taken as a basis and the program was supplemented by copyright of practical developments. These include topics of seminars in which the tasks of 
teaching academic writing are solved with the active use of appropriate information and communication technologies. These are, first of all, multifunctional word processors and online text verification services, the development of which is presented in this section. In section devoted to teaching academic reading discusses the importance of electronic sources of scientific information, including library services, as well as considered the use of online services to create mental maps and reviewing forms. Work with electronic lexicographic services supports training in the proper use of professional terminology. Capabilities of modern anti-plagiarism detection systems are included in the laboratory work on the expert evaluation of scientific articles, as well as in the requirement applications of the result of the anti-plagiarism test to the article [5]. For the task of writing a scientific article, recommendations are made on the use of systems of automated translation of article metadata. Exploring opportunities the timeconsuming process automatization of creating item lists and in-text links using bibliographic managers.

As a result of mastering the discipline, the student should demonstrate a number of competencies within which he will show a willingness to apply the acquired skills in the process of professional activity, implying knowledge of the grammatical phenomena necessary for reading, translation and editing; complex syntactic constructions of scientific and business speech; technology for structuring an academic text; features of the scientific style of written nd oral texts; vocabulary representing a neutral scientific style, as well as the structure of business writing; different ways of setting hypotheses and building evidence strategies.

In connection with the goal which is outlined in the introduction of discipline, students receive a number of tasks during the realization of the educational process, namely: to master the ability to freely read the original literature of the relevant branch of knowledge in a foreign language; to work with bibliography; to draw up information extracted from foreign sources in the form of a translation, library-research paper, abstract; to compare the content of different sources of information on the problem of scientific research, to evaluate critically the opinion of the authors; to organize properly their own ideas, to substantiate and express them clearly and convincingly; to apply the results of mastering the discipline in professional activities. Using the tools of electronic educational resources, students develop the skill of owning a specialty, i.e. the skill of using a professional conceptual and terminological apparatus and the main part of the vocabulary is represented in the form of neutral and scientific topics on a wide and narrow profile, as well as the units of general vocabulary for the development of oral speech. Students demonstrate an advanced style of written communication and the basics of analyzing their own scientific research [3]

\section{RESULTS DISCUSSION}

Undoubtedly, as the advantages of using various types of electronic educational resources in the process of study can be listed the following features: a large selection of various courses, multimedia products and manuals, the ability to work online, while being in different parts of the country or even the planet. However, at the same time, there are difficulties associated with the problem of selecting similar materials, the lack of face-to-face work with the student the author's are forced to work out electronic educational resources taking into account the specifics of the educational program and the requirements for students [6] [7] .

It should be mentioned that students can also train in classrooms or libraries using the Sanako Study 1200 software multimedia system when studying the "Academic writing" discipline. This computer program is an addition to the electronic educational resource and through it it becomes possible to automate the assessment of the level of knowledge of grammar and vocabulary of students, as well as to establish the process of using multimedia tools in electronic notebooks with tasks using both open questions that require a complete and detailed answer and test - with the option of choosing the right answer in real time.

The undoubted advantage of the complex is also the function of the "Round Table", which makes it possible to arrange a discussion between students, dividing them into small subgroups and appointing the main speaker, leading a specific topic [8]. Practicing the practical material is carried out by different ways: watching videos on a specific topic, completing tasks aimed at expanding the vocabulary and developing skills in using general scientific vocabulary and terms, developing basic vocabulary material, with particular attention being paid to stable word combinations, phraseological phrases, phrasal verbs and basic theoretical terminology [9]. Writing an essay on a given topic, as well as various types of abtracts, selecting keywords, searching and working out a list of sources used are also productive types of work for checking the formation of students' competencies. The content of the course of any discipline implies the presence of a glossary with additional material for study and also the possibility of using various specialized online translators (Multitran, Smart Cat, Transation Memory, ABBYY Lingvo, Multiplex) makes it possible to choose the most accurate equivalents when translating from a foreign language into Russian and vice versa.

\section{CONCLUSION}

1. In the course of the analysis of sources and methods of work in the Internet space, it was determined that electronic educational resources meet all the requirements set for tools for working with students, namely they make it possible to efficiently and creatively organize the educational process at the university and allow to fully 
harakteristik studenta, Voprosy obrazovanija, №1, 2016. URL: [https://cyberleninka.ruarticle/n/plagiat-ispisyvanie-v-rossiyskih-vuzah-rol-obrazovatelnoysredy-i-individualnyh-harakteristik-studenta] (data obrashhenija: 20.03.2020) DOI: $10.17323 / 1814-9545-$ 2016-1-84-109

[6] O.V. Vishtak, Napravlenija programmnoj realizacii jelektronnyh obrazovatel'nyh resursov, Sbornik nauchnyh trudov SWorld, Vyp. 2, T. 5, Odessa: KUPRIENKO, 2013. pp. 36-39

[7] A. Bilyalova, D. Salimova, T. Zelenina, Higher Education in Digital Age, Advances in Intelligent Systems and Computing, Vol.1114, AISC, Is, 2020, pp. 207-219 https://doi.org/10.1007/978-3-030-37737-3_19

[8] A. Suhkova, A. Bilyalova, D. Khairullina, ELearning Efficiency: Linguistic Subject Taught via Electronic Educational Resources, Advances in Intelligent Systems and Computing, Vol.1114 AISC, Is, 2020, pp. 197-206 https://doi.org/10.1007/978-3-03037737-3_18

[9] G. Gilfanova, D. Salimzanova, The Problem of Historical Choice in East German Literature (Johannes Bobrowki in Context of the Postwar Literature of the 1950s-1970s, Journal of History Culture and Art Research, № 6(5), 2017, pp. 342-348 DOI: http://dx.doi.org/10.7596/taksad.v6i5.1253

[10] I.N. Rozina Cifrovaja gramotnost' v kurse «Akademicheskoe pis'mo» (na russkom jazyke). URL: [https://cyberleninka.ru/article/n/tsifrovaya-gramotnostv-kurse-akademicheskoe-pismo-na-russkom-yazyke]. (data obrashhenija: 27.03.2020).

[11] S. Rimer, A campus fad that's being copied, Internet plagiarism seems on the rise, Ethics in the 21st century, edited by M.A. Trent, Pearson Education, 2005, pp.195-199.

[12] N.E. Esenina, Ispol'zovanie jelektronnyh spravochno-informacionnyh sistem $\mathrm{v}$ obuchenii professional'no orientirovannomu inostrannomu jazyku, Vysshee obrazovanie segodnja, 2012, № 3, pp. 65-69.

[3] Rabochaja programma discipliny "Akademicheskoe pis'mo" / napravlenija podgotovki 45.04.02 "Lingvistika" Biljalova A.A. Naberezhnye Chelny, 2016, 36 p.

[4] S. Bailey, Academic Writing: A Handbook for International Students, New York, 3rd edition, Routledge, 2011, p. 314 ISBN 0-203-83165-9

[5] E.D. Shmeleva, Plagiat i spisyvanie v rossijskih vuzah: rol' obrazovatel'noj sredy i individual'nyh
[13] E.M. Clarke, E.A. Emerson, Design and synthesis of synchronization skeletons using branching time temporal logic, in: D. Kozen (Eds.), Workshop on Logics of Programs, Lecture Notes in Computer Science, vol. 131, Springer, Berlin, Heidelberg, 1981, pp. 52-71. DOI: https://doi.org/10.1007/BFb002 